\title{
FENOMENA KINERJA INDUSTRI PERBANKAN SYARIAH DI MALUKU
}

\author{
Dety Aryani Relubun', Muhammad H. Holle², Maimuna Toatubun ${ }^{3}$ \\ ${ }^{1}$ Manajemen Keuangan Syariah, IAIN Ambon, Maluku, Indonesia \\ ${ }^{2}$ Ekonomi Syariah, IAIN Ambon, Maluku, Indonesia \\ ${ }^{3}$ Manajemen Bisnis Syariah, IAIN Ambon, Maluku, Indonesia
}

\begin{tabular}{l}
\hline ARTICLE INFORMATION \\
\hline ISSN: 2579-7204 (Online) \\
ISSN: 0216-4132 (Print) \\
DOI: $10.26487 /$ jbmi.v18i3.18914 \\
\hline SUBMISSION TRACK \\
\hline Received : 26 November 2021 \\
Final Revision : 08 Februari 2022 \\
Available Online : 24 February 2022 \\
\hline KATA KUNCI \\
\hline Pertumbuhan aset, Perbankan Syariah
\end{tabular}

Pertumbuhan aset, Perbankan Syariah

\begin{abstract}
ABSTRAK
Penelitian ini bertujuan mengetahui pertumbuhan aset industri Perbankan Syariah di Maluku dan menawarkan strategi meningkatkan pertumbuhan aset industri perbankan syariah di Maluku. Jenis penelitian adalah lapangan Penelitian ini adalah penelitian lapangan dengan pendekatan kualitatif dan menggunakan studi kasus serta menelaah dokumen statistik pada industri Perbankan Syariah di Maluku. Informan dalam penelitian ini adalah manager Perbankan Syariah, terdiri dari Bank Muamalat Indonesia Cabang Ambon dan Bank Syariah Mandiri Cabang Ambon. Pengumpulan data menggunakan teknik wawancara, dokumentasi dan studi pustaka. Pengolahan data menggunakan olah data deskriptif kualitatif kemudian dianalisis dengan teknik induktif. Hasil penelitian ini menemukan bahwa pertumbuhan aset industri perbankan syariah di Maluku dihadapkan dengan kendala internal dan eksternal yang menjadi faktor pelambatan pertumbuhan aset industri perbankan syariah di Maluku. Faktor internal terdiri dari kondisi modal kerja, pembiayaan konsumsi dan faktor ekternal meliputi pembiayaan perbankan syariah lebih didominasi oleh murabahah dibanding pembiayaan lainnya.
\end{abstract}

KEYWORD
Asset growth, Islamic banking

CORRESPONDENCE

Phone : 085243066461

Email : detyaryanirelubun@gmail.com

\begin{abstract}
This study aims to identify the growth of the assests of Islamic banking industry in Maluku and recommend the effective strategies to help increasing the asset growth of Maluku's Islamic Banking industry. This study is a field research that used a qualitative approach and is a case study that examined statistical documents of Islamic Banking industry in Maluku. There were two main informants in this study, they were the managers from Islamic banking industry consisting of Bank Muamalat Indonesia Ambon Branch and Bank Syariah Mandiri Ambon Branch. Hence, the interview was used as the data collection technique as well as documentation and literature study. Whereas data processing used qualitative descriptive data that were analyzed by inductive technique. The results of this study found that the growth of the assets of Islamic banking industry in Maluku experienced internal and external constraints which become the biggest factors in slowing the growth of the assets of Maluku's Islamic banking industry. The Internal factors comprise working
\end{abstract}


capital condition and consumption financing while the financing of Islamic banking are more dominated by murabahah than other financings.

\section{PENDAHULUAN}

Pesatnya perkembangan bisnis syariah baru dirasakan di Indonesia dalam kurun waktu 20 tahun terakhir, pelopor perbankan syariah yang pertama kali berdiri pada tahun 1991 adalah bank Muamalat, bank syariah pertama yang dijinkan oleh pemerintah. Perbankan syariah di Indonesia telah menhadirkan bank syariah maupun bank konvensional yang membuka cabang bank syariah dan turunannya berupa puluhan bank pengkreditan rakyat syariah maupun BMT di seantero negeri. Keterlambatan perkembangan perbankan syariah, tentu saja tidak terlepas dari kebijakan pemerintah. (Azis, 2018) Perbankan syariah merupakan salah satu aspek dari ekonomi islam yang melarang penggunaan sistem bunga dalam perekonomian khususnya perbankan, karena sistem tersebut dianggap riba yang dilarang oleh agama.

Dampak dari kebijakan pemerintah terhadap pertumbuhan perbankan syariah terlihat nyata di lapangan. Perkembangan perbankan syariah di Indonesia dari tahun ke tahun semakin meningkat dengan adanya bank umum syariah dan unit usaha syariah berdasarkan outlook perbankan syariah tahun 2018, bank umum syariah berjumlah 17 , unit usaha syariah berjumlah 24 dan BPRS sejumlah 160, dengan total aset sebesar Rp 296.262 Milyar. Industri perbankan syariah syariah khususnya sektor perbankan, tumbuh $15 \%$ setiap tahunnya, meski di Indonesia market share perbankan syariah masih dibawah 5\% namun bank syariah telah memiliki 2.412 kantor yang tersebar di 33 provinsi seluruh Indonesia.Memang jika dibandingkan dengan total aset perbankan nasional, aset perbankan syariah masih kecil (Statistik Perbankan Syariah OJK, 2018).

Di Maluku sendiri perbankan syariah mulai beroperasi pada tahun 2010, dalam perjalanannya pertumbuhan aset perbankan syariah di Maluku masih negatif -24,67\%. Penurunan ini seiring dengan penurunan pertumbuhan DPK dan PYD. Maluku juga memiliki market share terendah sepanjang tahun 2017 sebesar 1,89\% di samping nusa tenggara timur 0,48\%, Sulawesi Utara 0,98\%, Papua 1,06\%, dan Bali 1,21\%. Namun secara keseluruhan nilai aset perbankan syariah 5 provinsi tersebut mengalami peningkatan dibandingkan tahun 2016. Kondisi tersebut mau tidak mau membuat 
Perbankan Syariah di Maluku harus lebih menyiapkan diri mengadapi tantangan sedemikian berat kedepan (Otoritas jasa keuangan, 2019).

Sedikitnya hingga kini ada tiga bank syariah dioperasikan di Maluku, yakni Bank Muamalat, Mandiri Syariah dan Panin Dubai Syariah. Tentu ketiga bank ini akan berusaha merebut pangsa pasar. Menjadi catatan bahwa Bank Panin Syariah adalah bank yang diinvestasikan dari Dubai Uni Emirat Arab. Untuk itu menarik meneliti kinerja Industri Perbankan Syariah di Maluku dalam kaitannya dengan tantangan, peluang dan selanjutnya menawarkan strategi untuk menaikan pertumbuhan aset. Dari latar belakang penulis tertarik menganalisis yang pertama bagaimana pertumbuhan aset industri perbankan syariah di Maluku dan kedua bagaimana strategi meningkatkan pertumbuhan aset industri perbankan syariah di Maluku.

Adapun tujuan penulis melakukan penelitian ini adalah untuk mengetahui pertumbuhan aset isdustri perbankan syariah di Maluku dan strategi untuk meningkatkan pertumbuhan aset industri perbankan syariah di Maluku.

\section{TINJAUAN PUSTAKA}

Berdasarkan Undang-Undang No. 7 Tahun 1992 tentang perbankan sebagaimana telah diubah dengan Undang-Undang No.10 Tahun 1998, jenis bank di indonesia terdiri dari dua kelompok yaitu bank umum dan bank perkreditan rakyat (BPR). Dalam undang-undang tersebut dijelaskan bahwa bank umum adalah bank yang melaksanakan kegiatan usaha secara konvensional dan/atau berdasarkan prinsip syariah yang dalam kegiatannya memberikan jasa dalam lalu lintas pembayaran. Dalam menjalankan kegiatan usahanya bank umum dapat memilih satu dari tiga pilihan yaitu seluruhnya beroperasi secara konvensional, seluruhnya beroperasi secara syariah, atau melakukan kegiatan usaha secara konvensional sekaligus juga melakukan kegiatan usaha berdasarkan prinsip syariah (Azis, 2018).

Bank umum syariah adalah Bank syariah yang dalam kegiatannya memberikan jasa dalam lalu lintas pembayaran sedangkan BPRS adalah Bank syariah yang dalam kegiatannya tidak memberikan jasa dalam lalu lintas pembayaran. Selain itu, UU Perbankan mengenal Unit Usaha Syariah (UUS) yaitu unit kerja dari kantor pusat bank 
umum konvensional yang berfungsi sebagai kantor induk dari kantor atau unit yang melaksanakan kegiatan usaha berdasarkan prinsip syariah, yaitu prinsip hukum Islam berdasarkan Fatwa yang dikeluarkan oleh lembaga yang memiliki kewenangan dalam penetapan Fatwa di bidang syariah. Dengan demikian, berdasarkan sistem hukum Indonesia, Fatwa yang dikeluarkan oleh Dewan Syariah Nasional (DSN) merupakan sumber hukum dalam pembentukan regulasi perbankan syariah, khususnya bagi Otoritas Jasa Keuangan (OJK) dan Bank Indonesia dalam menerbitkan peraturan. Implementasi prinsip syariah inilah yang menjadi pembeda antara perbankan konvensional dan perbankan syariah (Abubakar \& Handayani, 2017).

Kegiatan usaha bank menurut UU No 10 Tahun 1998 adalah sebagai lembaga intermediasi keuangan atau lembaga perantara keuangan dengan kegiatan utamanya menghimpun dana dari masyarakat dalam bentuk simpanan dan menyalurkan kembali kepada masyarakat dalam bentuk kredit atau bentuk-bentuk lainnya dalam rangka meningkatkan taraf hidup rakyat banyak. Bisnis perbankan memiliki tujuan untuk memperoleh keuntungan optimal dengan memberikan pelayanan berupa jasa keuangan kepada masyarakat (Dewi \& Tenaya, 2017).

Menurut Iqbal (1997) dalam (Al-Ghifari et al., 2020) tujuan dari sistem ekonomi islam yang secara khusus memberikan penekanan yang sama pada dimensi etika, moral, sosial dan spritual dalam upaya meningkatkan keadilan dan pembangunan masyarakat secara keseluruhan. Hal ini menurutnya sangat berbeda dengan sistem keuangan konvensional yang memusatkan pada aspek transaksi keuangan dan ekonomi saja. Tujuan khusus adanya perbankan syariah selain memberikan jasa keuangan yang halal bagi masyarakat muslim, sistem perbankan syariah diharapkan dapat memberikan kontribusi bagi tercapainya tujuan sosial (kemanusiaan) dari sistem ekonomi Islam. Oleh karena itu, kemunculan lembaga perbankan yang menggunakan nama syariah bukan hanya berdasarkan faktor permintaan pasar semata atau orientasi keuangan dan ekonomi saja akan tetapi diwujudkan atas dasar nilai-nilai kemanusiaan, yang mampu memecahkan masalah perekonomian yang dialami masyarakat dan sanggup meningkatkan martabat manusianya. Dengan begitu kehahadiran perbankan syariah 
dengan sendirinya akan mampu membawa perubahan perekonomian masyarakat muslim ke arah yang jauh lebih baik.

Industri perbankan syariah di Indonesia mengalamai pertumbuhan yang bervariasi sesuai dengan pertumbuhan ekonomi nasional. Pengembangan industri perbankan syariah di Indonesia dilandasi oleh Undang-Undang (UU) yang dikeluarkan oleh Pemerintah, maupun kebijakan-kebijakan yang dikeluarkan oleh otoritas perbankan. Salah satu UU yang melandasi awal perkembangan Perbankan syariah adalah UndangUndang No.21 Tahun 2008 tentang Perbankan Syariah yang terbit tanggal 16 Juli 2008. Dengan Undang-Undang tersebut, maka pengembangan industri perbankan syariah nasional memiliki landasan hukum yang cukup kuat, sehingga mendorong pertumbuhan industri ini lebih cepat. Percepatan Pertumbuhan perbankan syariah di Indonesia, sampai saat ini terus didorong oleh otoritas perbankan, yaitu Otoritas Jasa keuangan menuju industri perbankan syariah yang sehat, berkelanjutan, dan berkontribusi positif dalam mendukung pembangunan ekonomi yang berkualitas (Apriayanti, 2017).

Kinerja keuangan bank adalah suatu gambaran sampai di mana tingkat keberhasilan yang dicapai oleh bank dalam kegiatan operasionalnya. Kinerja keuangan perbankan menjadi faktor utama dan sangat penting untuk menilai keseluruhan kinerja perbankan itu sendiri. Kinerja suatu bank dapat dinilai dengan melakukan analisis terhadap laporan keuangannya. Berdasarkan laporan itu dapat dihitung rasio keuangan untuk dapat menilai tingkat kesehatan bank (Dewi \& Tenaya, 2017).

Kegiatan operasional bank syariah haruslah berlandaskan prinsip syariah yaitu berdasarkan kepada Al-Qur'an dan hadist, sehingga bank tidak mengandalkan bunga melainkan bagi hasil. Dalam keuangan syariah harus pula dipenuhi ketentuan menghindari riba, gharar dan maysir, objek dan keseluruhan proses investasi harus halal, serta menjamin terlaksananya konsep kemaslahatan dalam menjalankan setiap aktivitas. Falsafah dasar beroperasinya bank syariah yang menjiwai seluruh hubungan transaksinya berprinsip pada tiga hal yaitu efisiensi, keadilan, dan kebersamaan. Efisiensi mengacu pada prinsip saling membantu secara sinergis untuk memperoleh keuntungan/margin sebesar mungkin. Keadilan mengacu pada hubungan yang tidak dicurangi, ikhlas, dengan persetujuan yang matang atas proporsi 
masukan dan keluarannya. Kebersamaan mengacu pada prinsip saling menawarkan bantuan dan nasihat untuk saling meningkatkan produktivitas.

Selain itu dalam kegiatan usaha atau kegiatan operasional perbankan syariah menganut tiga prinsip utama yaitu (Saidi, 2015) :

1. Prinsip keadilan

Prinsip ini tercermin dari penerapan imbalan atas dasar bagi hasil dan pengambilan margin keuntungan yang disepakati bersama antara bank dan nasabah.

2. Prinsip kesederajatan

Bank syariah menempatkan nasabah penyimpan dana, nasabah pengguna dana, maupun bank pada kedudukan yang sama dan sederajat. Hal ini tercermin dalam hak, kewajiban, risiko dan keuntungan yang berimbang diantara nasabah penyimpan dana, nasabah pengguna dana maupun bank.

\section{Prinsip ketentraman}

Produk-produk bank syariah telah sesuai dengan prinsip dan kaidah mu'amalah Islam (halal), antara lain ada unsur riba dan menerapkan zakaat harta. Dengan demikian nasabah merasakan ketentraman lahir maupun batin.

Berdasarkan pada 3 (tiga) prinsip utama tersebut, maka di dalam kegiatan pelayanan kepada masyarakat bank syariah menerapkan prinsip-prinsip dasar sebagai berikut:

a. Prinsip titipan atau simpanan

Prinsip titipan atau simpanan (wadi'ah) dapat diartikan sebagai titipan murni dari satu pihak ke pihak lain, baik individu maupun badan hukum yang harus dijaga dan dikembalikan kapan saja penyimpan menghendaki. Atau dengan kata lain sebagai transaksi penitipan barang/uang antara pihak yang mempunyai barang/uang dengan pihak yang diberi kepercayaan dengan tujuan untuk menjaga keselamatan, keamanan, serta keutuhan barang/uang.

b. Prinsip bagi hasil

Prinsip bagi hasil adalah suatu prinsip yang meliputi tatacara pembagian hasil usaha antara penyedia dana dengan pengelola dana dan tidak bertentangan dengan prinsip-prinsip syariah. 
c. Prinsip jual beli

Prinsip jual beli merupakan suatu sistem yang menerapkan tata cara jual beli, di mana bank akan membeli terlebih dahulu barang yang dibutuhkan atau menunjuk nasabah sebagai agen bank untuk melakukan pembelian barang atas nama bank, kemudian bank menjual barang tersebut kepada nasabah dengan harga sejumlah harga beli ditambah keuntungan.

d. Prinsip sewa

Prinsip sewa merupakan transaksi sewa menyewa barang antara bank dengan nasabah, setelah masa sewa berakhir, barang sewaan dikembalikan kepada pihak bank atau boleh diperjanjikan barang tersebut untuk dijual kepada nasabah penyewa.

e. Prinsip jasa

Bank syariah dapat melakukan berbagai pelayanan jasa perbankan kepada nasabah dengan mendapat imbalan atau keuntungan.

Menurut Scanning dalam (Huda, 2015) aset merupakan sejumlah harta yang dimiliki dan dilaporkan oleh bank syariah untuk mendukung kegiatan operasional perusahaan, diukur dari jumlah aset terakhir yang sudah dilaporkan kepada bank indonesia dalam satuan nominal dan persen.

Menurut standar akuntansi pemerintah (SAP), aset adalah sumber daya yang dapat memberikan manfaat ekonomi dan/atau sosial yang dikuasai atau dimiliki oleh pemerintah atau perusahaan, dan dapat diukur dalam satuan uang, termasuk didalamnya sumber daya non keuangan yang diperlukan untuk penyediaan jasa bagi masyarakat umum dan sumber daya yang dipelihara karena alasan sejarah dan budaya.

\section{METODE PENELITIAN}

Penelitian ini adalah lapangan Penelitian ini adalah field research (penelitian lapangan) dengan pendekatan kualitatif dan menggunakan case study serta menelaah dokumen statistik pada industri Perbankan Syariah. Informan dalam penelitian ini adalah manager Perbankan Syariah, terdiri dari bank Muamalat, bank syariah mandiri, 
bank Dubai Panin Syariah dan pimpinan OJK Maluku. Para informan ini dipilih karena sangat terkait dengan kinerja Perbankan Syariah.

Teknik pengumpulan data dalam penelitian yaitu dengan data sekunder dan di lengkapi dengan wawancara ke beberapa informan. Dalam penelitian ini, pengolahan data menggunakan olah data deskriptif kualitatif yaitu menjabarkan hasil penelitian sebagaimana adanya. Data yang telah didapatkan dari hasil penelitian pustaka kemudian dianalisis dengan teknik induktif, yaitu pola pikir yang bermula dari prinsipprinsip khusus kemudian diaplikasikan pada informasi yang bersifat umum. Analisis data berlangsung secara bersama-sama dengan proses pengumpulan data dengan alur tahapan yaitu reduksi data, penyajian data serta penyimpulan dan verifikasi dan kesimpulan akhir. Tahapan teknik pengolahan data meliputi reduksi data, penyajian data dan penarikan kesimpulan (Sugiyono, 2017).

\section{HASIL DAN DISKUSI}

Berdasarkan hasil wawancara selama dengan para narasumber yang berasal dari pihak regulator, yaitu Bank Indonesia (BI), Otoritas Jasa Keuangan (OJK), Perbankan Syariah yang berasal dari Bank Muamalat Indonesia (BMI), dan Bank Syariah Mandiri (BSM) diperoleh hasil bahwa terdapat faktor internal dan eksternal yang menjadi penyebab perlambatan pertumbuhan aset bank syariah di Maluku, akan tetapi faktor internal ini lebih dipicu oleh adanya faktor eksternal.

Perlambatan pertumbuhan aset perbankan syariah sudah mulai terasa pada tahun 2017 hingga 2019. Secara umum perlambatan, dapat dilihat dari sisi eksternal dan internal. Sebagaimana disampaikan (Hermanto, 20202) Secara eksternal, perlambatan terjadi karena disebabkan oleh kondisi ekonomi dimana terjadi perlambatan dalam pertumbuhan ekonomi di dunia termasuk di Indonesia. Hal ini menyebabkan nilai tukar Rupiah melemah terhadap US Dollar, turunnya IHSG, dan turunnya daya beli masyarakat. Kondisi makro ekonomi ini berpengaruh terhadap kinerja industri perbankan syariah yang mengakibatkan lambatnya pertumbuhan bank syariah baik dari sisi aset maupun liabilitas.

Salah satu indikator pertumbuhan bank syariah adalah jumlah aset, dimana dari sisi aset perbankan syariah di Maluku mengalami perlambatan terhadap jumlah 
pembiayaan yang disalurkan kepada masyarakat. Dalam hal ini, industri perbankan syariah di Maluku semakin mereview pembiayaan yang sudah dan yang akan diberikan. Manajemen melakukan kontrol dan perbaikan kualitas pembiayaan untuk mengurangi terjadinya pembiayaan yang bermasalah.

Data yang diterima dari OJK pembiayaan yang bermasalah terlihat dalam rasio Net Performing Finance (NPF) industri perbankan syariah di Maluku tahun 2018 berada dikisaran 4,68 persen dan di bulan Juni 2019, NPF industri perbankan syariah di Maluku hanya 0,73 persen. Berikut pertumbuhan aset industri perbankan syariah di Maluku yang dapat dilihat pada perkembangan indikator utamanya.

Tabel 1. Perkembangan Indikator Utama Bank Syariah di Maluku 2017-2018

\begin{tabular}{|c|c|c|c|c|c|c|c|c|}
\hline \multirow{3}{*}{ Indikator } & \multicolumn{4}{|c|}{ Nominal (dalam Rp Miliar) } & \multicolumn{4}{|c|}{ Pertumbuhan (\% yoy) } \\
\hline & \multicolumn{2}{|c|}{2017} & \multicolumn{2}{|c|}{2018} & \multicolumn{2}{|c|}{2017} & \multicolumn{2}{|c|}{2018} \\
\hline & III & IV & III & IV & III & IV & III & IV \\
\hline Aset & 370.02 & 372.45 & 404.52 & 414.84 & (21.34) & $(24,67)$ & 9.32 & 11.38 \\
\hline DPK & 347.60 & 357.01 & 397.18 & 395.37 & 7.29 & 0.61 & 14.26 & 10.74 \\
\hline Giro & 43.11 & 12.55 & 13.45 & 12.80 & (36.88) & (81.66) & (68.80) & 2.04 \\
\hline Tabungan & 199.84 & 233.15 & 244.88 & 260.91 & 5.41 & 22.26 & 22.54 & 11.90 \\
\hline Deposito & 104.65 & 111.31 & 138.85 & 121.65 & 58.36 & 16.24 & 32.68 & 9.29 \\
\hline Kredit (Lokasi Proyek) & 328.37 & 345.88 & 393.45 & 392.73 & 1.78 & 16.23 & 19.82 & 13.54 \\
\hline Modal Kerja & 15.91 & 14.26 & 12.70 & 14.34 & (91.72) & (92.57) & (20.17) & 0.55 \\
\hline Investasi & 177.56 & 177.92 & 194.46 & 187.76 & 261.73 & $1,314.46$ & 9.52 & 5.53 \\
\hline Konsumsi & 134.90 & 153.69 & 186.28 & 190.62 & 65.69 & 65.32 & 38.09 & 24.03 \\
\hline \% RIM & 94.47 & 96.88 & 99.06 & 99.33 & & & & \\
\hline$\%$ NPL & 0.53 & 0.46 & 0.48 & 0.37 & & & & \\
\hline
\end{tabular}

Sumber: data sekunder bank syariah, 2017-2018.

Dalam laporan Bank Umum ini menunjukkan aset Bank Syariah di propinsi Maluku mengalami peningkatan dibandingkan triwulan sebelumnya. Jika pada triwulan III aset Bank Syariah mencapai 9,32 persen atau 404,52 miliar, angka ini naik pada pada triwulan IV 2018, asset bank syariah tumbuh sebesar 414.84 milyar atau 11,38\%. Aset ini naik jauh dari dua tahun sebelumnya 2017. Kondisi menunjukkan adanya peningkatan proporsi yang menginformasi terjadinya peningkatan pada pertumbuhan asset bank syariah pada triwulan III ke triwulan IV 2018 dari tahun sebelumnya. 
Sementara itu, giro mengalami peningkatan pertumbuhan selama triwulan IV 2018, dari terkontraksi 13.45 milyar atau 68,80\% menjadi tumbuh 12.80 milyar atau 2,04\%.

Sementara itu Pertumbuhan pembiayaan tercatat mengalami penurunan, pada tahun 2018 triwulan IV $0.55 \%$ lebih rendah jika dibandingkan dengan triwulan sebelumnya 20.17\%. Penurunan ini dipicu oleh adanya penurunan pertumbuhan pada komponen tabungan dan deposito. Pada triwulan IV 2018, tabungan tumbuh sebesar $11,90 \%$, lebih rendah dibandingkan triwulan sebelumnya sebesar $32,68 \%$.

Menurut (Murady,2020) rasio NPF yang tinggi menyebabkan perbankan syariah harus lebih banyak menyediakan cadangan modal untuk meng-cover jumlah pembiayaan yang bermasalah. Hal ini juga akan berdampak mengurangi laba yang diperoleh oleh bank syariah. Kondisi laba yang menurun merupakan indikasi kinerja perusahaan yang melemah sehingga manajemen bank harus merubah strategi pembiayaannya.

Bank Syariah lebih banyak menghadapi kendala eksternal, misalnya dari sisi liabilitas, Dana Pihak Ketiga (DPK) yang minim karena didominasi sumber dana jangka pendek, edukasi, sosialisasi kepada masyarakat yang minim, dan keterbatasan jaringan bank. Dari sisi liabilitas Dana Pihak Ketiga perbankan syariah didominasi oleh sumber dana jangka pendek yaitu dalam bentuk deposito dan tabungan. Dana DPK dalam bentuk deposito ini juga merupakan dana mahal sehingga perbankan syariah semakin merasakan besarnya tambahan biaya dana. Biaya modal yang mahal umumnya berada pada segmentasi korporat, di mana segmentasi ini sensitif terhadap imbal hasil yang ditawarkan.

Tantangan lainnya yang dihadapi Industri Perbankan Syariah di Maluku adalah modal, karena ini merupakan salah satu aspek yang sangat penting didalam sektor perbankan. Termasuk dalam upaya mengembangkan kualitas bank syariah yang ada di Maluku. Penyediaan modal yang kuat akan memberikan kemudahan dalam upaya pengembangan perbankan di Maluku. Permasalahan yang paling mendasar adalah, (1) keraguan pemodal terhadap prospek keberhasilan bank syariah di masa yang akan datang, (2) perhitungan bisnis pemodal yang tidak dilandasai rasa nilai 
ubudiyah sehingga terkesan semata-mata hanya mencari keuntungan duniawi dan merasa keberatan jika harus menginvestasikan sebagian dananya di bank syariah sebagai modal, (3) terakhir adalah regulasi Bank Indonesia dalam menempatkan modal yang tinggi.

Begitupun dengan sumberdaya manusia, banyaknya bank syariah di Indonesia yang semakin menjamur tidak diimbangi dengan Sumber Daya Manusia yang berkualitas, sehingga perkembangan sektor perbankan menjadi lambat. Sistem bank syariah memang masih belum lama dikenal di Indonesia, disamping itu lembaga pendidikan dan pelatihan masih terbatas, sehingga tenaga terdidik dan berpengalaman dibidang perbankan syariah baik dari sisi bank pelaksana maupun bank sentral pengawas dan peneliti bank (Suherman, 2020). Pengembangan SDM sangat dibutuhkan karena keberhasilan pengembangan bank syariah pada level mikro sangat ditentukan oleh kualitas manajemen dan tingkat pengetahuan serta keterampilan mengelola bank. SDM-nya memerlukan persyaratan pengetahuan general di bidang perbankan, memahami implementasi prinsip-prinsip syariah dalam praktek perbankan serta mempunyai komitmen untuk menerapkannya secara istiqamah.

Terkait keterbatasan dan tantangan sumberdaya manusia perbankan syariah, hasil penelitian Jannah menyatakan hal ini merupakan tantangan terberat, di mana selama ini SDM perbankan syariah yang tersedia masih jauh dari harapan baik jumlah maupun kualitas. Oleh karena itu, dibutuhkan upaya keras dari seluruh stakeholders industri keuangan syariah sehingga mampu meningkatkan profesionalisme lembaga keuangan ini sehingga dapat memicu pertumbuhannya. Hambatan-hambatan internal inilah yang mengakibatkan perbankan syariah di Maluku kalah bersaing dengan perbankan konvensional di mana mereka dapat menaikan bunga simpanan untuk menarik dana korporasi sehingga dapat terjadi pengalihan sebagian dana simpanan dari perbankan syariah ke perbankan konvensional.

Dilain sisi, pertumbuhan aset bank syariah di Maluku juga mengalami hambatan karena faktor internal lainnya seperti pembiayaan perbankan syariah lebih didominasi oleh murabahah. Murabahah merupakan pembiayaan yang bersifat konsumtif dengan 
akad jual-beli. Bila kondisi ekonomi melambat, sektor murabahah yang merupakan pembiayaan konsumtif juga turut melemah, hal ini dikarenakan menurunnya daya beli masyarakat sehingga sebagian besar masyarakat menahan kebutuhan terhadap barang-barang konsumsi. Dengan demikian minat masyarakat untuk mengajukan pembiayaan konsumtif juga ikut menurun. Hal ini terjadi karena industri perbankan syariah di Maluku lebih fokus pada pembiayaan mudharabah dibanding pembiayaan lainnya seperti musyarakah. Padahal Dana pihak ketiga (DPK) yang berasal dari masyarakat atau nasabah selain diperoleh dari pembiayaan mudharabah juga bisa diperoleh dari giro wadiah, tabungan wadiah, dan pembiayaan musyārakah maupun pembiayaan lainnya.

Faktor lain yang menghambat adalah kurangnya kesadaran masyarakat keberadaan akan perbankan syariah. Padahal sudah dituliskan di dalam al- Qur'an bahwa Allah Swt mengharamkan riba dan menghalalkan jual beli. Selama ini perbankan syariah sudah berulang kali mencoba mengajak dan mengajukan kerjasama dengan institusi maupun perorangan dalam hal pengelolaan keuangan secara syariah namun masih banyak penolakan dari institusi yang notabene adalah institusi Islam dan juga perorangnya. Alasannya adalah karena keuangan mereka sudah dikelola oleh bank lain (konvensional) sebelumnya. Mereka mengaku tidak enak kalau pengelolaannya dialihkan ke bank syariah.

Menurut Alma (2020) dalam segi produk dan program yang ditawarkan oleh bank syariah di Maluku jauh lebih kompetitif dibandingkan bank konvensional karena ada sistem bagi hasil yang lebih menguntungkan. Alasan lainnya dari para nasabah yang sudah menenamkan investasinya di bank konvesional enggan berhijrah ke bank syariah karena tidak ingin merepotkan diri dengan pengurusan administrasi.

Masih kurang bervariasinya pembiayaan perbankan syariah jika dibandingkan dengan produk kredit bank konvensional juga menjadi faktor internal penyebab perlambatan pertumbuhan bank syariah. Dengan varian produk pembiayaan yang masih cukup terbatas menyebabkan bank syariah kurang optimal mengambil pasar potensial yang seharusnya dimiliki oleh bank syariah, yaitu pasar yang menginginkan mengajukan pendanaan dari bank yang bebas dari riba atau pasar yang idealis. 
Sumber lain menyebutkan faktor internal penyebab perlambatan pertumbuhan bank syariah adalah efisiensi dalam kegiatan operasional bank. Bank syariah masih kalah bersaing dengan perbankan konvensional dalam hal efisiensi terutama dalam kondisi ekonomi yang kurang stabil, sehingga equivalent rate pembiayaan yang diminta oleh bank syariah relatif lebih besar dibanding kredit bank konvensional. Hal ini dapat menyebabkan berkurangnya daya tarik dari nasabah untuk mengambil pembiayaan pada bank syariah, karena nasabah bank mayoritas masih bersifat rasional, artinya dalam melakukan transaksi masih menilai untung-rugi dari sisi nominal dana. Masyarakat yang memiliki motif ideologi dalam bertransaksi dengan bank syariah masih sangat terbatas.

Nasabah di Maluku sudah lama tereduksi dengan bank konvesional, jadi walaupun kita bilang ada perbedaan, tapi masih enggan untuk berpindah ke Bank Syariah. Begitupun dengan kurangnya daya tarik nasabah terhadap produk yang ditawarkan, bukan karena produknya tapi ketidakpahaman mereka tentang jenis produknya itu. Mereka juga masih menghitung untung rugi berinvestasi di bank syariah. Kalo dari sisi ideologi, sepertinya tidak begitu berpengaruh di Maluku, karena kehidupan masyarakat Maluku yang toleran. Jadi masih sangat terbatas.

Dilihat dari sisi modal kerja Bank Syariah di Maluku terus mengalami penurunan sejak tahun 2017 hingga 2018. Hal ini juga menyebabkan kontribusi industri perbankan syariah di Maluku terhadap perbankan syariah nasional masih sangat melambat. Jika kurs IDR / USD naik tentunya menyebabkan total aset akan ikut naik. Kondisi ini berbanding terbalik dengan industri perbankan syariah di Maluku.

\section{KESIMPULAN DAN SARAN}

Fenomena adanya perlambatan pertumbuhan bank syariah disebabkan oleh beberapa faktor internal dan faktor eksternal. Faktor internal terdiri dari adanya dominasi oleh sektor retail khususnya UMKM dan akad murabahah (jual-beli) pada segmentasi pembiayaan bank syariah, masih minimnya variasi pembiayaan bank syariah jika dibandingkan dengan produk kredit bank konvensional, masih kurang 
efisiennya bank syariah dalam menjalankan kegiatan operasionalnya, dominasi dana deposito yang berbiaya mahal dalam skala jangka pendek pada DPK bank syariah, masih kurang efisiennya bank syariah dalam kegiatan operasional, dan masih terbatasnya jumlah jaringan kantor dan cabang bank syariah untuk menjangkau nasabah bank syariah. Begitupun keterbatasan sumberdaya manusia Perbankan Syariah. Adapun faktor ekternal perlambatan terjadi disebabkan oleh kondisi ekonomi yang melambat di dunia termasuk di Indonesia dengan indikator nilai tukar Rupiah melemah terhadap US Dollar, turunnya IHSG, inflasi, dan turunnya daya beli masyarakat.

Strategi yang dapat dilakukan industri perbankan syariah di Maluku untuk menaikan pertumbuhan aset dan memberikan kontribusi bagi perbankan syariah secara nasional adalah perbankan syariah di Maluku dapat mempertimbangkan untuk menyalurkan pembiayaan pada sektor-sektor unggulan di Maluku serta sektor usaha lain yang relatif tahan dalam keadaan ekonomi yang melambat sehingga dapat meningkatkan dana pihak ketiga (DPK). Dalam hal pendanaan, perbankan syariah dapat menambah jumlah jaringan, variasi produk, dan layanan yang lebih menarik sehingga menambah komposisi dana retail bagi perusahaan. Bank syariah juga perlu mengembangkan channeling ke kalangan konglomerat dan nasabah pemerintah termasuk dunia kampus. Untuk melakukan hal tersebut bank syariah membutuhkan tambahan dana dalam bentuk tambahan modal atau pendanaan lain seperti sukuk yang dapat digunakan untuk menambah kekuatan modal untuk ekspansi penambahan jumlah cabang. Memperbaiki pelayanan dan diversifikasi produk yang dapat dipahami mudah oleh masyarakat. Perbankan syariah wajib menerapkan marketing syariah sebagai salah satu solusi menghadapi praktik pemasaran bank konvensional yang kurang menjunjung tinggi nilai - nilai moralitas serta hak dan kewajiban pembeli kurang dihargai dalam transaksi jual beli, keadaan ini dirasa masyarakat sangat merugikan konsumen, sehingga terjadi perubahan persepsi masyarakat yang menginginkan kondisi pasar yang jauh dari praktik kebohongan dan kecurangan.

\section{DAFTAR PUSTAKA}


Al-Ghifari, M., Handoko, L. H., \& Yani, E. A. (2020). Analisis Kinerja Perbankan Syariah Di Indonesia Dan Malaysia Dengan Pendekatan Maqashid Indeks. Jurnal ekonomi dan perbankan syariah, 3(2). https://doi.org/10.46899/jeps.v3i2.160

Azis, M. T. (2018). Analisa Kinerja Perbankan Syariah Indonesia Ditinjau Dari Maqasyid Syariah. Al-Amwal: Jurnal Ekonomi Dan Perbankan Syari'ah, 10(1). https://doi.org/10.24235/amwal.v10i1.2808

Abubakar L, \& Handayani, T . (2017). Percepatan Pertumbuhan Perbankan \ Syariah Melalui Implementasi Tata Kelola Syariah. Jurnal Law and Justice, Vol. 2 No. 2 Oktober 2017.

Apriyanti H.W. (2017). Perkembangan Industri Perbankan Syariah di Indonesia: Analisis Peluang dan Tantangan. Jurnal Maksimum, Vol. 1. No. 1 September Tahun 2017., h. 16.

Alma T, (2020). Manager Marketing Bank Muamalat Cabang Ambon. Wawancara, tanggal 21 Juli 2020.

Bandjar F. (2020). Sub Branch Manager Bank Muamalat Cabang Ambon. "Wawancara", tanggal 20 Juli 2020

Budiman Amrin. (2020). Branch Operations \& Service Manager Bank Syariah Mandiri Kantor Cabang Ambon, "Wawancara" Tanggal 10 Juli 2020.

Basalamah M. R, \& Rizal M., (2018). Perbankan Syariah. Malang: Empatdua Media.

Creswell J. W. (2015). Penelitian Kualitatif dan Desain Riset; Memilih Diantara Lima Pendekatan. Diterjemahkan dari Qualitative Inquiry \& Research Design: Choosing Among Five Approches, Third edition First Published 2014, Edisi ke3, Yogjakarta: Pustaka Pelajar, Cet. I, .

Dewi, P. P. E. R., \& Tenaya, A. I. (2017). Pengaruh Penerapan GCG Dan Ukuran Perusahaan Terhadap Kinerja Keuangan Perbankan Di BEI Periode 2013-2016. EJurnal Akuntansi Universitas Udayana, 21(1).

Hermanto, B. ( 2020 ) Kepala Otoritas Jasa Keuangan Maluku. "Wawancara". Tanggal 12 April 2020.

Hery. (2015). Analisis Kinerja Manajemen. PT. Grasindo. Jakarta

Huda N. (2015). Ekonomi Pembangunan Islam. Jakarta:Kencana.

Otoritas Jasa Keuangan. "Laporan Perkembangan Keuangan Syariah 2016". Jakarta, Juni 2017. 
JURNAL BISNIS, MANAJEMEN, DAN INFORMATIKA (JBMI) - VOL 18 NO. III (2022)

Sugiyono. (2017). Metode Penelitian Kuantitatif, Kualitatif dan R\&D. Cet ke-26, (Bandung: Penerbit Alfabeta.

Saidi, Z. (2015). Tidak Syariahnya Bank Syariah. Cetakan ke 5. Delokomotif. Jogyakarta.

Suherman, A. (2020). Branch Manager Bank Muamalat Cabang Ambon, "Wawancara", tanggal 26 Juli 2020. 